\title{
PERANCANGAN MODUL KONTROL TEKANAN RUANGAN BERBASIS ARDUINO PADA SISTEM VENTILASI RSG-GAS
}

\section{DESIGN OF ROOM PRESSURE CONTROL MODULE BASED ARDUINO IN RSG-GAS VENTILATION SYSTEM}

\author{
Jazid Uchti Namir ${ }^{1}$, Kiswanto ${ }^{1}$, Cahyana ${ }^{1}$, Ferdy Triyuandika ${ }^{1}$ \\ ${ }^{1}$ Pusat Reaktor Serba Guna-BATAN, Kawasan Puspiptek Serpong \\ Email: jazid-uchti@batan.go.id.
}

Diterima: 21 Oktober 2021, diperbaiki : 28 Oktober 2021, disetujui : 28 Oktober 2021

\begin{abstract}
ABSTRAK
PERANCANGAN MODUL KONTROL TEKANAN RUANGAN BERBASIS ARDUINO PADA SISTEM VENTILASI RSG-GAS. Salah satu fungsi dari sistem ventilasi RSG-GAS adalah mengatur tekanan negatif setiap ruang di dalam gedung RSG-GAS. Tekanan negatif diatur menggunakan modul kontrol tekanan dengan input sinyal dari transducer untuk menggerakan aktuator damper. Tujuan dari tulisan ini adalah merancang modul kontrol tekanan ruangan agar dapat menggantikan modul kontrol tekanan lama yang masih memiliki tampilan analog dan barang diskontinu. Perancangan ini terdiri atas perancangan hardware dan software. Perancangan hardware menggunakan komponen-komponen yaitu modul HW 685, Arduino, Display OLED 0,96 inch, relay shield, potensiometer, switch auto/manual dan push button. Alur proses kendali tekanan yaitu sinyal dari transducer diterima modul HW 685. selanjutnya sinyal diteruskan ke arduino untuk diprogram. Sinyal hasil pembacaan ditampilkan pada display dan menggerakkan aktuator damper melalui relay shield. Perancangan software menggunakan software Arduino IDE. Perancangan software terdiri atas pembuatan program otomatis dan manual. Program otomatis beroperasi berdasarkan nilai Setting Point (SP) yang diberikan untuk mempertahankan nilai tekanan dan menggunakan perhitungan kontrol proposional, sedangkan program manual berdasarkan push button untuk menaikan dan menurunkan tekanan. Perancangan kontrol tekanan digital akan digunakan pada sistem ventilasi RSG-GAS.
\end{abstract}

Kata kunci : Sistem ventilasi, kontrol tekanan, arduino

\begin{abstract}
DESIGN OF ROOM PRESSURE CONTROL MODULE BASED ARDUINO IN RSG-GAS VENTILATION SYSTEM. One of the functions of the RSG-GAS ventilation system is to control the negative pressure of each room in the RSG-GAS building. The negative pressure is controlled using a pressure control module with a signal input from transducer to drive the damper actuator. The purpose of this paper is to design a room pressure control module in order to replace the old pressure control modules that still using analog display and discontinued items. This design consists of designing hardware and software. The hardware design uses components such as HW 685 module, Arduino, 0.96 inch OLED display, relay shield, potentiometer, auto/manual switch and push button. The flow of the pressure control process, that is the signal from the transducer is received by the HW 685 module. then the signal is forwarded to Arduino to be programmed. The readout signal is displayed on the display and drives the damper actuator through the relay shield. The design of the software uses the Arduino IDE software. Software design consists of automatic and manual programming. The automatic program operates based on the given Setting Point (SP) to maintain the pressure value and uses proportional control calculations, while the manual program is based on push button to increase and decrease pressure. The digital pressure control design will be used in the RSG-GAS ventilation system.
\end{abstract}

Keywords : ventilation system, pressure control, arduino 


\section{PENDAHULUAN}

$\mathrm{R}$ eaktor Serba Guna G.A. Siwabessy (RSG-GAS) memiliki sistem ventilasi yang berfungsi mengendalikan udara yang masuk dan keluar gedung reaktor. Sistem ventilasi reaktor juga berfungsi mempertahankan suhu, kelembaban dan tekanan ruang. Suhu dan kelembaban dipertahankan untuk menjaga integritas komponen di dalam reaktor dan kenyamanan manusia bekerja, sedangkan tekanan ruang dipertahankan untuk menjaga tekanan negatif di dalam gedung reaktor. Tekanan negatif di dalam gedung reaktor bervariasi nilainya dan ditetapkan berdasarkan potensi radiasi dan kontaminasi udara yang berasal dari ruang tersebut. Di dalam RSG-GAS, terdapat empat sistem udara resirkulasi ruang yang dipertahankan tekanannya yaitu sistem udara resirkulasi balai operasi (KLA31), sistem udara resirkulasi balai eksperimen (KLA32), sistem udara resirkulasi ruang sistem pendukung (KLA33) dan sistem udara resirkulasi primary cell (KLA34). Parameter persyaratan tekanan negatif tiap sistem yaitu KLA31 -1,5 mbar, KLA32 -0,5 mbar, KLA33 -1 mbar dan KLA34 2 mbar. ${ }^{11]}$

Tekanan negatif ruang didapatkan dari nilai pembacaan transducer yang membandingkan nilai tekanan ruang di dalam gedung reaktor dengan tekanan di luar gedung reaktor (tekanan atmosfer). Hasil pembacaan tersebut diteruskan pada modul kontrol tekanan untuk mengendalikan katup damper pasokan udara segar (KLA10).

Modul kontrol tekanan pada sistem ventilasi RSG-GAS sudah mengalami penuaan dan merupakan barang diskontinu yang tidak tersedia lagi di pasaran. Modul tersebut masih menggunakan pembacaan analog dan tidak dapat dikembangkan sesuai kemajuan teknologi yang ada sekarang. Pada makalah ini, dilakukan perancangan modul kontrol tekanan digital untuk menggantikan modul kontrol tekanan lama yang masih analog. Modul kontrol tekanan digital ini diharapkan dapat mengendalikan tekanan ruang agar tetap pada nilai parameter yang dipersyaratkannya.
Perancangan modul kontrol tekanan menggunakan arduino sebagai pusat dari sistem kendalinya. Penggunaan arduino telah banyak dilakukan seperti untuk pengukuran konsentrasi $\mathrm{CO}_{2}$, suhu dan kelembaban pada penilaian pasokan udara luar sistem AC Split, aplikasi pemantauan kualitas udara ruang dan sistem kontrol aliran pendingin pada menara pendingin PLTN [2][3][4]. Pada makalah ini arduino digunakan untuk kontrol tekanan ruang dengan melakukan pemantauan tekanan ruang dari transducer dan mengendalikan buka tutup katup damper pasokan udara segar.

Untuk menampilkan data digital, perancangan ini menggunakan display OLED dengan antarmuka I2C (Inter Integrated Circuit). Antarmuka I2C menggunakan 2 wire yaitu SDA dan SCL yang dapat diintegrasikan dengan pin arduino. Selanjutnya data yang diolah arduino dapat ditampilkan dalam bentuk digital pada display. ${ }^{[5]}$

\section{TEORI}

\section{Arduino}

Arduino merupakan perangkat elektronik open-source yang memiliki input dan output yang dapat diprogram. ${ }^{[6]}$ Salah satu jenis papan arduino adalah arduino uno. Arduino uno merupakan sebuah microcontroller yang berbasis ATmega328P. Microcontroller ini memiliki 14 digital input/output pin dengan 6 pin diantaranya dapat digunakan sebagai PWM output, 6 analog input, clock speed 16 $\mathrm{MHz}$ dan koneksi USB. Tegangan minimum untuk arduino adalah $5 \mathrm{~V}$, dan disarankan menggunakan tegangan sekitar $7-12$ V. ${ }^{[7]}$

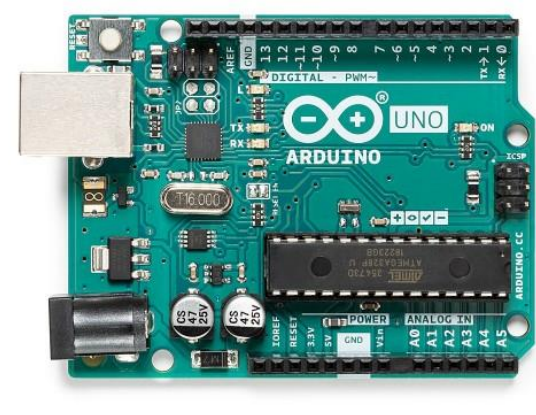

Gambar 1. Arduino Uno 


\section{HW 685}

HW 685 adalah modul elektronik yang berfungsi mengubah sinyal arus lemah $(0 / 4-20 \mathrm{~mA})$ menjadi tegangan $\mathrm{DC}$ $0-3,3 / 5 / 10 \mathrm{~V}$. besar tegangan output yang diinginkan dapat dipilih dengan melakukan jumper pada pin $\mathrm{J1}$. $^{[8]}$

Tabel 1. Konfigurasi Pin J1 HW 685

\begin{tabular}{|c|c|c|}
\hline Tegangan & \multicolumn{2}{|c|}{ Pin J1 } \\
\cline { 2 - 3 } Output & $1-2$ & $3-4$ \\
\hline $0-3,3 \mathrm{~V}$ & disconnected & disconnected \\
\hline $0-5 \mathrm{~V}$ & connected & connected \\
\hline $0-10 \mathrm{~V}$ & connected & disconnected \\
\hline
\end{tabular}

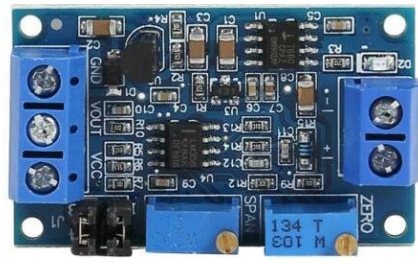

Gambar 2. HW 685

\section{Display OLED 0.96 inch}

Display OLED (Organic Light-Emitting Diode) merupakan suatu modul elektronik yang berfungsi untuk menampilkan huruf dan karakter (alphanumeric). Display OLED memiliki ukuran yang beragam, salah satunya adalah berukuran 0.96 inch dengan ketelitian pixel 128 x 64. Display ini dapat diprogram menggunakan microcontroller melalui komunikasi I2C. spesifikasi dari display ini adalah ukuran display $25 \mathrm{~mm} \times 14 \mathrm{~mm}$, tegangan kerja $5 \mathrm{VDC}$, arus $20 \mathrm{~mA}$ dan komunikasi $12 \mathrm{C}$ 7-bit address. ${ }^{[9]}$ Penelitian ini menggunakan display OLED sebagai penampil digital.

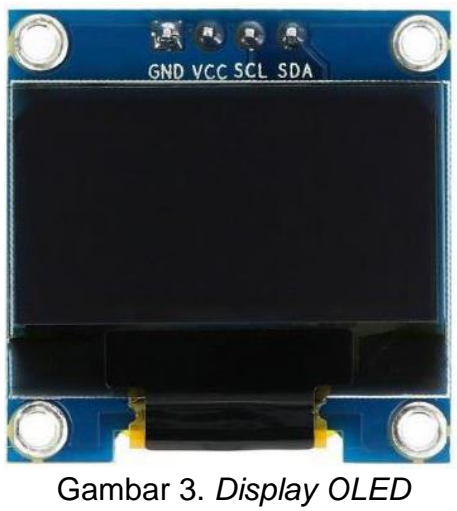

Relay Shield V3.0

Relay shield V3.0 adalah sebuah modul relay generasi ke-3 yang kompatibel dengan arduino uno. Relay shield ini menyediakan 4 relay dengan masing-masing relay memiliki kontak Normally Open (NO) dan Normally Close (NC). Tegangan masukan untuk menggerakkan relay adalah 4,75-5,25 $\mathrm{V}$ dengan arus kerja 8-250 mA, dan kemampuan kontak NO/NC adalah tegangan switching 250VAC/ 30VDC dengan arus switching 15A/7A. ${ }^{10]}$

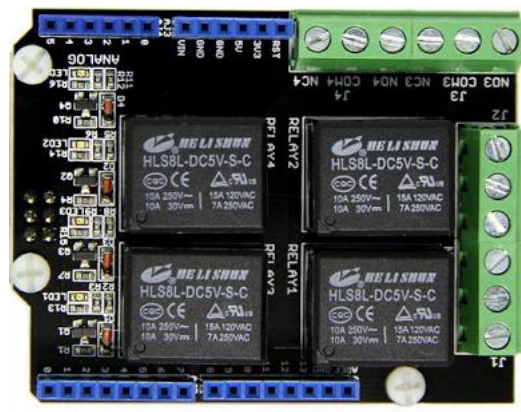

Gambar 4. Relay Shield V3.0

\section{Arduino IDE}

Arduino IDE merupakan sebuah perangkat lunak menggunakan bahasa $\mathrm{C}$ yang bersifat open-source dan dapat menulis program yang dapat diunggah ke papan arduino. ${ }^{[11]}$ Arduino IDE menyediakan berbagai jenis library program yang memudahkan pengguna untuk membuat program yang akan ditanamkan pada papan arduino. 


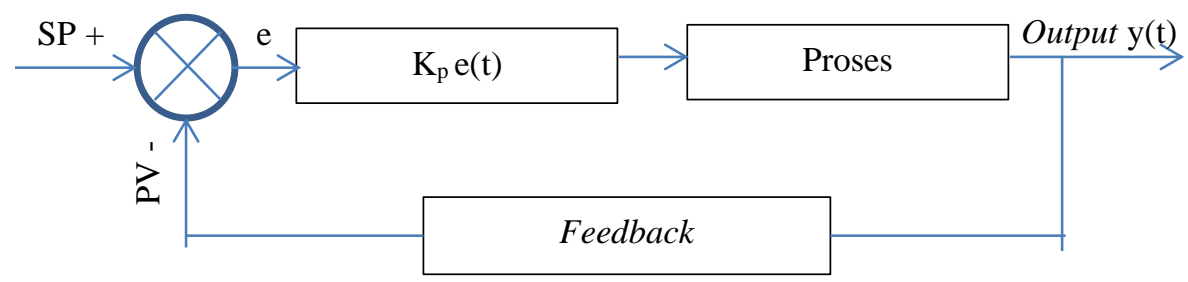

Gambar 6. Close Loop Kontrol Proposional

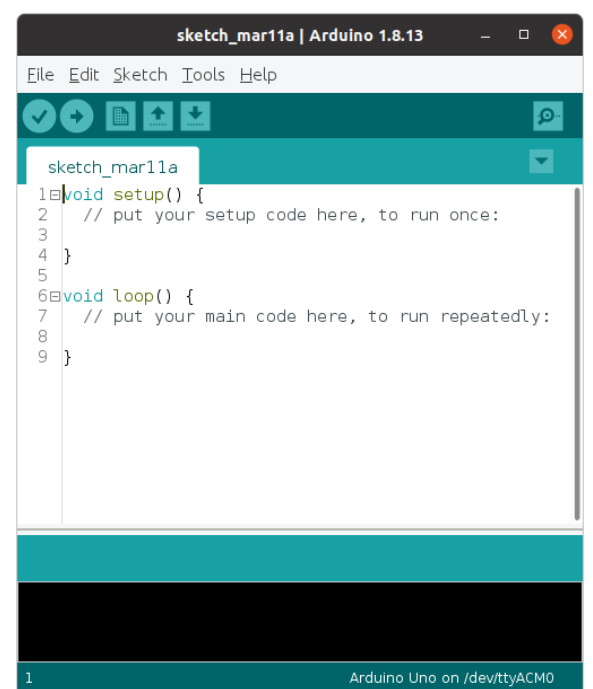

Gambar 5. Software Arduino IDE

\section{Kontrol Proposional}

Kontrol proposional adalah kontrol yang mengendalikan nilai error dengan memberikan masukan pengali $\mathrm{Kp}$ (Konstanta proposional). Nilai pengali $\mathrm{Kp}$ yang sangat besar menyebabkan sistem tidak stabil, dan nilai pengali $\mathrm{Kp}$ yang sangat kecil menyebabkan sistem menjadi lama untuk stabil..12] Alur proses kontrol proposional ditunjukkan pada Gambar 6.

Berdasarkan Gambar 6, sinyal dari kontrol proposional dapat dinyatakan sebagai berikut:

$$
e(t)=S P-P V
$$

$y(t)=K_{p} \cdot e(t)$

Dimana $y(t)$ adalah sinyal kontrol, dan $\mathrm{e}(\mathrm{t})$ sinyal error. Nilai $\mathrm{e}(\mathrm{t})$ didapatkan dari selisih SP (Set Point) dan PV (Present Value).

\section{METODOLOGI}

\section{Identifikasi}

Pada sistem ventilasi RSG-GAS, memiliki berbagai jenis nilai tekanan negatif pada setiap ruangan. Perbedaan nilai tekanan negatif tiap ruang menyebabkan beragamnya nilai jangkauan transducer tiap ruang. Hal ini perlu diidentifikasi guna menentukan skala pembacaan sensor pada modul kontrol tekanan. Sistem ventilasi RSG-GAS memiliki transducer dengan besar jangkauan pembacaan tekanan yang berbeda-beda yang ditunjukkan pada Tabel 2. Nilai maksimum dan minimum dari pembacaan transducer dijadikan nilai batas pembacaan sensor pada input analog modul kontrol tekanan.

Tabel 2. Nilai Jangkauan Transducer

\begin{tabular}{ccc}
\hline \multirow{2}{*}{ Sistem } & \multicolumn{2}{c}{ Transducer (mbar) } \\
\cline { 2 - 3 } & Minimum & Maksimum \\
\hline KLA31 & -5 & 0 \\
\hline KLA32 & -3 & +2 \\
\hline KLA33 & -3 & +2 \\
\hline KLA34 & -5 & 0 \\
\hline
\end{tabular}

Pembacaan nilai tekanan ruang dilakukan konversi nilai sebanyak 4 kali. Pertama yaitu dari tekanan mbar dikonversi menjadi arus lemah 0-20 mA. Pada tahap ini terjadi di transducer. Kedua yaitu dari arus 0 $20 \mathrm{~mA}$ dikonversi menjadi tegangan 0-5 VDC. Konversi ini terjadi pada modul HW 685. Ketiga yaitu dari tegangan 0-5 VDC dikonversi menjadi skala ADC (Analog Digital Converter) 0-1023. tahap terakhir yaitu dari skala ADC 01023 dikonversi menjadi nilai tekanan mbar untuk ditampilkan di display. Tahap ketiga dan keempat terjadi di dalam program arduino. 


\section{Perancangan Hardware}

Perancangan hardware pada modul kontrol tekanan digital digunakan untuk mengetahui pengkabelan antar tiap komponen. Parancangan ini dimaksudkan juga untuk menentukan pin analog input dan digital input output yang digunakan pada papan arduino. Penentuan pin arduino ini selanjutnya digunakan untuk inisialisasi input dan output pada perancangan software. Blok diagram hardware ditunjukkan pada Gambar 7 dan tabel 3 menunjukkan konfigurasi input output arduino.

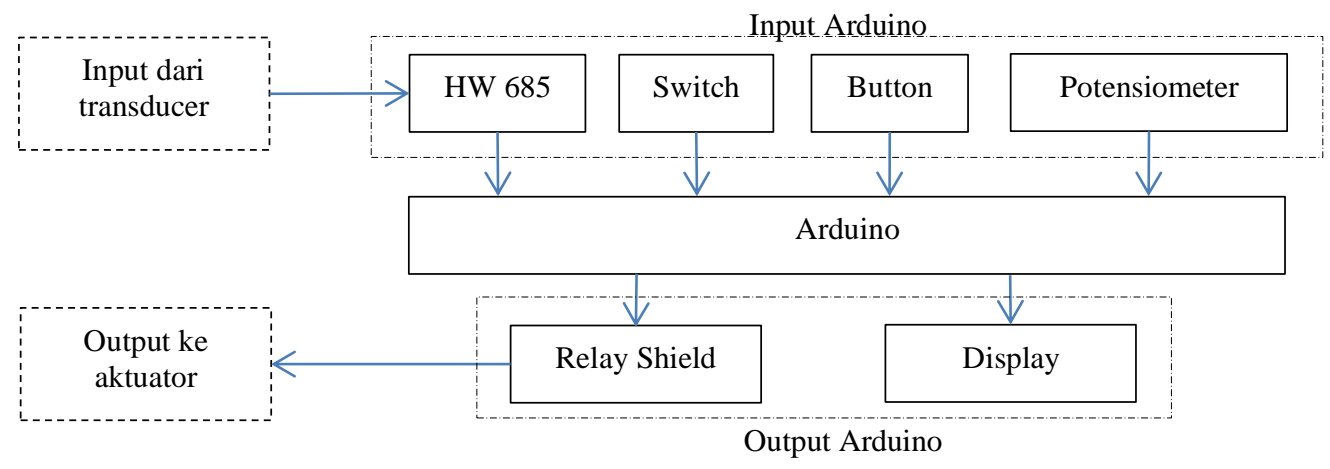

Gambar 7. Blok Diagram Hardware

Tabel 3. Konfigurasi input dan output arduino

\begin{tabular}{|c|c|c|}
\hline \multicolumn{2}{|c|}{ Komponen } & Arduino \\
\hline \multirow{3}{*}{$\begin{array}{c}\text { Display OLED } \\
0,96 \text { inch }\end{array}$} & GND & GND \\
\cline { 2 - 3 } & VCC & $+5 V$ \\
\cline { 2 - 3 } & SCL & SCL/A5 \\
\cline { 2 - 3 } & SDA & SDA/A4 \\
\hline \multirow{3}{*}{ HW 685 } & GND & GND \\
\cline { 2 - 3 } & VCC & VIN \\
\cline { 2 - 3 } & VOUT & A0 \\
\hline \multirow{3}{*}{ Potensiometer } & 1 & $+5 \mathrm{~V}$ \\
\cline { 2 - 3 } & 2 & $\mathrm{~A} 1$ \\
\cline { 2 - 3 } & 3 & GND \\
\hline \multirow{2}{*}{ Button + } & 1 & $+5 \mathrm{~V}$ \\
\cline { 2 - 3 } & 2 & $\mathrm{D} 8$ \\
\hline \multirow{2}{*}{ Button - } & 1 & $+5 \mathrm{~V}$ \\
\cline { 2 - 3 } & 2 & $\mathrm{D} 9$ \\
\hline \multirow{2}{*}{ Switch A/M } & 1 & $+5 \mathrm{~V}$ \\
\cline { 2 - 3 } & 2 & $\mathrm{D} 10$ \\
\hline \multirow{2}{*}{ Relay Shield } & $\mathrm{D} 4$ & $\mathrm{D} 4$ \\
\cline { 2 - 3 } & $\mathrm{D} 5$ & $\mathrm{D} 5$ \\
\hline
\end{tabular}

\section{Perancangan Software}

Perancangan software ini dilakukan untuk pembuatan program kendali tekanan otomatis dan manual menggunakan software Arduino IDE. Perancangan ini terdiri atas pembuatan beberapa sub program diantara- nya sub program otomatis dan sub program manual. Rancangan program otomatis ditunjukkan pada Gambar 8.

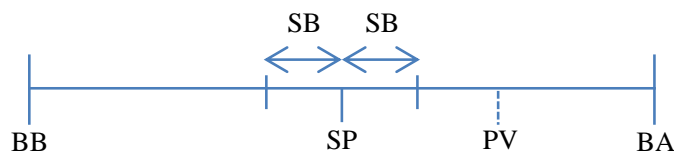

Gambar 8. Rancangan Program Otomatis

Pada Gambar 8, BB dan BA merupakan batasan jangkauan pengukuran transducer. SP merupakan nilai tekanan yang ingin dicapai dan dipertahankan. PV merupakan nilai tekanan terkini hasil pembacaan dari transducer. SB yaitu nilai batasan dari SP dimana jika PV berada pada daerah SB maka program tidak memberikan perintah ke aktuator untuk melakukan kompensasi nilai tekanan. Jika PV berada di luar daerah SB, maka program akan memerintahkan aktuator untuk membuka/ menutup sampai $\mathrm{PV}=\mathrm{SP}$ atau PV berada pada daerah SB. Tabel 4 menunjukkan arah gerak aktuator berdasarkan nilai PV, SP dan SB. 
Tabel 4. Arah gerak aktuator berdasarkan nilai PV, SP dan SB

\begin{tabular}{cc}
\hline Kondisi & Aktuator \\
\hline $\mathrm{PV}<(\mathrm{SP}-\mathrm{SB})$ & Membuka \\
\hline $\mathrm{PV}>(\mathrm{SP}+\mathrm{SB})$ & Menutup \\
\hline$(\mathrm{SP}-\mathrm{SB}) \leq \mathrm{PV} \leq(\mathrm{SP}+\mathrm{SB})$ & Diam \\
\hline
\end{tabular}

Proses PV menuju SP menggunakan perhitungan kontrol proposional yang ditunjukkan pada persamaan (1) dan (2) yaitu:

Error $=S P-P V$

Time Error $=\mid$ Error $\mid \times K p$

Time Error merupakan nilai waktu program memberikan perintah ke aktuator untuk beroperasi (buka/tutup). Aktuator damper akan bergerak menutup jika nilai Error positif dan aktuator damper akan bergerak membuka jika nilai Error negatif. Lamanya waktu buka dan tutup aktuator bergantung pada nilai Time Error. Nilai Time Error diatur melalui besar nilai Kp. Semakin besar nilai Kp maka semakin cepat nilai PV menuju SP dan sebaliknya, semakin kecil nilai Kp maka semakin lambat nilai PV menuju SP.

Rancangan program manual menggunakan push button sebagai perintah untuk menggerakkan aktuator. Jika push button + ditekan, maka aktuator akan bergerak membuka, sedangkan jika push button ditekan, maka aktuator akan bergerak menutup.

\section{HASIL DAN PEMBAHASAN}

\section{Hasil Perancangan Hardware}

Hasil perancangan hardware ditunjukkan pada Gambar 9. HW 685 menerima sinyal dari transducer untuk diteruskan ke arduino melalui ADC menggunakan pin $\mathrm{A} 0$. Sinyal yang masuk ke arduino diolah dan ditampilkan pada display melalui antarmuka I2C menggunakan pin SDA dan SCL. Hasil olah sinyal di dalam arduino digunakan untuk mengatur operasi aktuator melalui relay shield pada pin D4 dan D5. Nilai SP yang digunakan pada pengoperasian otomatis dikendalikan menggunakan potensiometer yang dihubungkan pada A1 pin arduino. Selanjutnya pada pengoperasian manual terdapat push button +, push button - dan switch $\mathrm{A} / \mathrm{M}$ yang masing-masing menggunakan pin arduino D8, D9 dan D10.

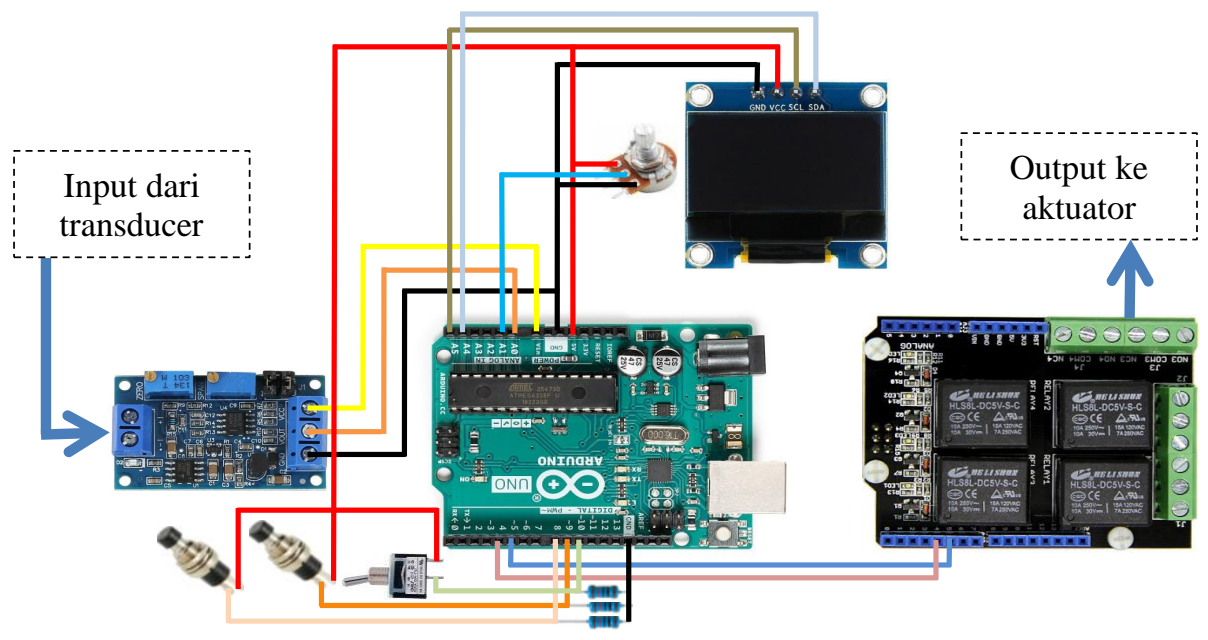

Gambar 9. Hasil Perancangan Hardware 


\section{Hasil Perancangan Software}

Hasil perancangan software terdiri atas beberapa sub program, yaitu sub program inisialisasi, sub program manual dan sub program otomatis.

\section{Sub program inisialisasi}

Hasil perancangan sub program inisialisasi ditunjukkan pada Gambar 10.

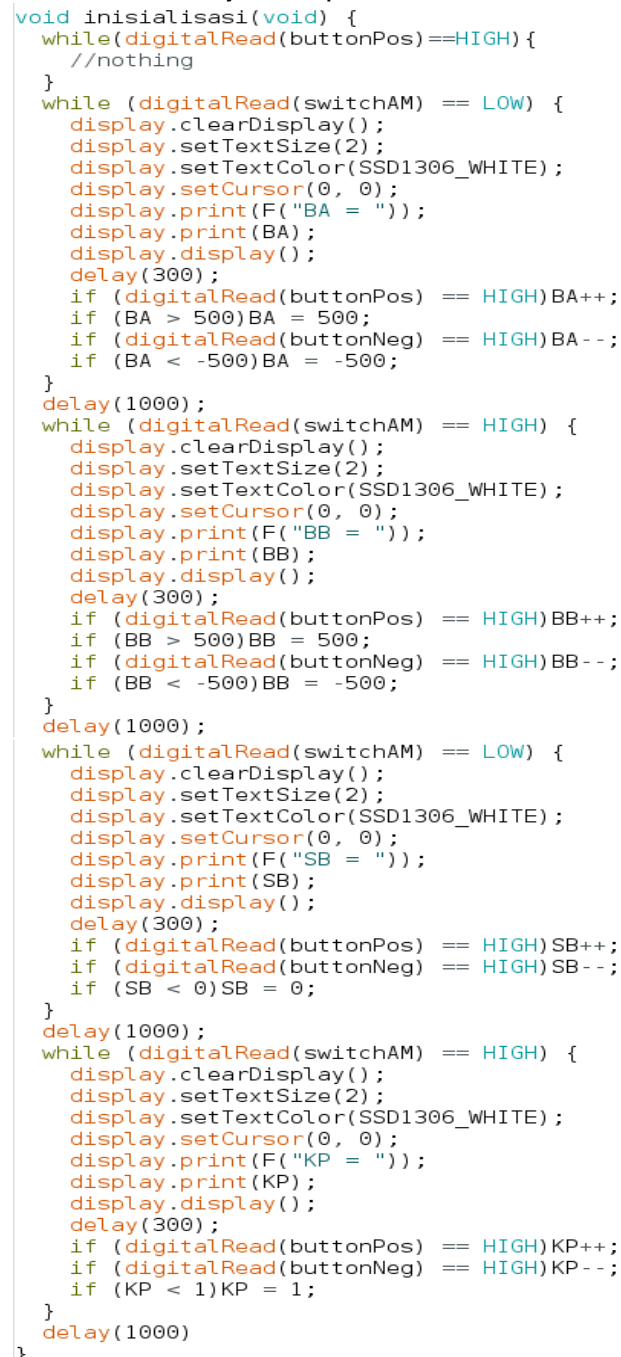

Gambar 10. Potongan Source Code Sub Program Inisialisasi

Sub program ini dieksekusi ketika modul hidup pertama kali, Switch A/M pada posisi manual dan push button + ditekan. Sub program ini dibuat untuk menentukan nilai BA, BB, SB dan Kp. Ketika masuk ke sub program ini, diminta untuk mengatur nilai BA dengan menekan push button + dan push button -. Untuk berpindah ke pengaturan selanjutnya, switch $\mathrm{A} / \mathrm{M}$ diposisikan otomatis dan program beralih untuk pengaturan nilai BB. Selanjutnya, Switch A/M diposisikan manual dan program beralih ke pengaturan nilai SB. Pada tahap terakhir dari sub program ini adalah pengaturan nilai $\mathrm{Kp}$ dengan memposisikan switch A/M ke otomatis. Untuk keluar dari sub program, switch A/M diposisikan manual dan program akan beralih ke sub program manual.

\section{Sub program manual}

Hasil perancangan sub program manual ditunjukkan pada Gambar 11.

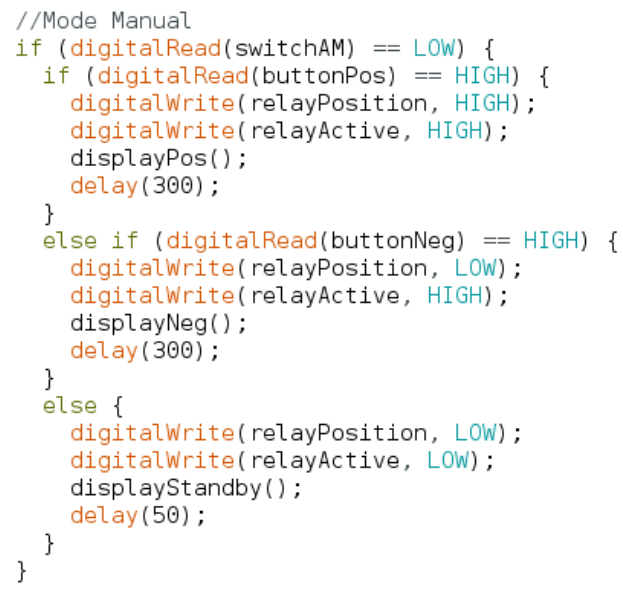

\section{Gambar 11. Potongan Source Code Sub Program Manual}

Sub program manual dieksekusi ketika switch A/M diposisikan manual. Pada sub program ini tekanan dikendalikan secara manual. Tekanan akan turun ketika push button - ditekan sehingga program akan memerintahkan aktuator untuk bergerak menutup. Selanjutnya tekanan akan naik ketika push button + ditekan sehingga program akan memerintahkan aktuator untuk bergerak membuka.

\section{Sub program otomatis}

Hasil perancangan sub program otomatis ditunjukkan pada Gambar 12. 


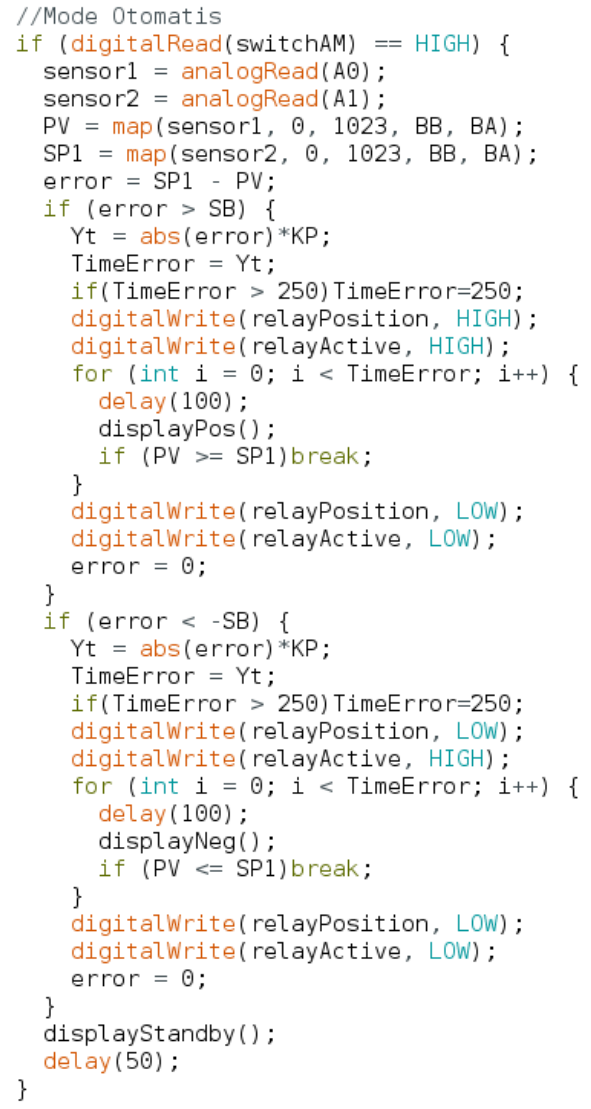

Gambar 12. Potongan Source Code Sub Program Otomatis

Sub program otomatis dieksekusi ketika switch A/M diposisikan otomatis. Sub program ini bekerja berdasarkan nilai SP yang diatur melalui potensiometer. Pada awal sub program, nilai PV dan SP dikonversi dari satuan $A D C$ ke satuan mbar dengan nilai maksimum BA dan nilai minimum BB. Selanjutnya, dilakukan perhitungan nilai Error yang didapatkan dari selisih antara PV dan SP. Setelah perhitungan nilai Error, dilakukan perhitungan nilai Time Error dari perkalian antara nilai absolut Error dengan Kp. Jika nilai absolut Error lebih besar dari nilai SB, maka program akan memerintahkan aktuator untuk bergerak. Nilai Error positif akan memerintahkan aktuator bergerak membuka selama (Time Error x 100) ms. Nilai Error negatif akan memerintahkan aktuator bergerak menutup selama (Time Error x 100) ms. Jika nilai absolut Error kurang atau sama dengan nilai SB, maka aktuator tidak beroperasi. Nilai PV, SP dan indikator buka/tutup ditampilkan ke display sebagai pembacaan digital. Tampilan display ditunjukkan pada Gambar 13.

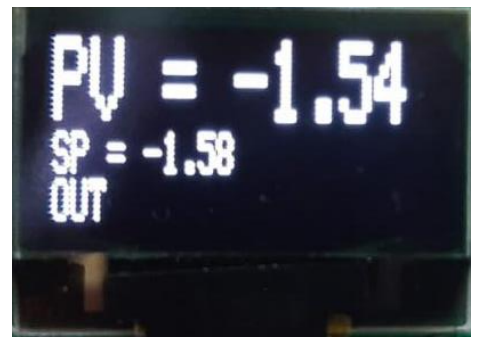

Gambar 13. Tampilan Display

\section{KESIMPULAN}

Perancangan kontrol tekanan ruang digital diharapkan dapat mengganti modul kontrol tekanan yang lama dengan fungsi kerja sama tetapi dengan tampilan yang sudah digital. Perancangan ini menggunakan arduino sebagai pusat kendali sehingga mudah dikembangkan lebih lanjut ke arah loT (Internet of Things) dengan menambahkan komponen lain seperti ethernet shield dan sebagainya. Rancangan ini diharapkan dapat diaplikasikan pada sistem ventilasi RSG-GAS seperti pada sistem KLA31, KLA32, KLA33 dan KLA34 sebagai pengatur tekanan ruang.

\section{UCAPAN TERIMAKASIH}

Dengan selesainya penelitian ini, kami mengucapkan terimakasih kepada PRSGBATAN yang telah memfasilitasi penelitian ini. Kami mengucapkan terimakasih juga kepada Ir. Yusi Eko Yulianto selaku Kepala PRSGBATAN dan Ir. Edison, M.Si selaku Koordinator Pemeliharaan Reaktor.

\section{DAFTAR PUSTAKA}

[1] LAK. RSG-GAS Rev.10.1. PRSG BATAN.

[2] A. Bimaridi, K. D. Putra, E. Djunaedy, and M. R. Kirom, "Assasment of Outside Air Supply for Split AC system - Part A: 
Affordable Instrument," Procedia Eng., vol. 170, pp. 248-254, 2017.

[3] S. Abraham and X. Li, "A cost-effective wireless sensor network system for indoor air quality monitoring applications," Procedia Comput. Sci., vol. 34, pp. 165-171, 2014

[4] A. Hossain, S. Islam, Z. Rahman, A. Z. M. Salahuddin, and A. S. Mollah, "An intelligent flow control system of coolant for a water reactor based cooling tower," Energy Procedia, vol. 160, pp. 566-573, 2019

[5] A. OO, "Design, simulation and implementation of an Arduino microcontroller based automatic water level controller with I2C LCD display," Int. J. Adv. Appl. Sci., vol. 9, no. 2, p. 77, 2020

[6] Anonim, "What is Arduino?", Arduino, 5 Februari 2018, [Online]. Tersedia: https://www.arduino.cc/en/Guide/Introdu ction [Diakses 5 Januari 2021]

[7] Electronic Component's Datasheet, [Online]. Tersedia:

https://www.alldatasheet.com/view.jsp?S
earchword=ATMEGA328P [Diakses 10 Januari 2021]

[8] Anonim, "HW-685 4-20mA Current Sensing", Turais Tech, 1 Januari 2021, [Online].

Tersedia:

https://docs.turais.de/docs/modules/hw6 85/ [Diakses 15 Januari 2021]

[9] Purbakawaca, Rady, "Monochrome 0.96" 128x64 OLED Graphic Display", Academia, 24 Februari 2019, [Online]. Tersedia:

https://www.academia.edu/38428432/M onochrome $0966128 \times 32$ OLED graph ic display pdf [Diakses 4 Februari 2021]

[10] Anonim, "Relay Shield v3.0", Seeed, 2016, [Online]. Tersedia: https://seeeddoc.github.io/Relay Shield v3.0/ [Diakses 4 Februari 2021]

[11] Anonim, "Arduino IDE 1.8.13", Arduino, [Online].

Tersedia: https://www.arduino.cc/en/software [Diakses 4 Februari 2021]

[12] A. R. Al Tahtawi, Y. Somantri, and E. Haritman, "Design and Implementation of PID Control-based FSM Algorithm on Line Following Robot," JTERA, vol. 1, pp. 23-30, 2016 